\title{
The Challenge of Arabization in Syria
}

\section{Taher Badinjki}

The eclipse of Arabic that took place in the last part of the eighteenth and the early nineteenth century was caused by several factors. This paper looks at the reasons for this eclipse and also sheds light on the revival of Arabic in the Arab world in general and in Syria in particular.

The conquest of Syria and Egypt by Salìm I in 1516 and 1517 marks a definite stage in the extension of Ottoman sway over the Arab world. His crushing victories made him the master of Iraq and Syria and enabled him to enter Cairo and establish his rule over Egypt. Under his successor, Sulaymān the Magnificent, the subjection of the Arab world was extended westward along the North African coast and southward as far as Yemen and Aden. Upon Sulaymān's death in 1566, the Ottomans ruled the Arab world from Algeria to the Arabian Gulf, and from Aleppo to the Indian Ocean. In addition to the sacred cities of Makkah, Madinnah, and Jerusalem, it embraced Damascus, the first capital of the Arab empire, and Baghdad, whose sciences had once illuminated the world. With varying fortunes, and frequently accompanied by war and revolt, the Ottoman Empire maintained itself in these territories until the end of the eighteenth century and the outbreak of the First World War in 1914.

At the beginning of the eighteenth century, the Ottoman Empire witnessed a movement of reform and reorganization under Abmad III (170330) and his successors. However, the Arab world did not seem to benefit very much from it. In addition, these reforms, intended primarily to arrest the Empire's decline and restore vitality to its system, sought to establish Turkish as the language of instruction. Later on, Arabic was abandoned and Turkish became the language of instruction in government schools and educational institutions. ${ }^{1}$ Only Arabic grammatical rules, which were indispensable for an understanding of Ottoman literature, were taught and, quite often, by Turkish teachers. ${ }^{2}$

Taher Badinjki was a Fulbright Scholar in Residence at the University of South Carolina, Columbia, South Carolina, when he presented this paper at the International Institute of Islamic Thought, Herndon, Virginia, on 16 April 1993. He teaches at the University of Aleppo, Syria.

'See Șāțī' al Hușrī, Hawla al Qawmīyah al 'Arabiyah (Beirut: Dār al 'Ilm li al Malayīn, 1961), 104-10 and Kemal Karpat, ed., Political and Social Thought in the Contemporary Middle East, (New York, 1968), pp.45-6, 55-8.

${ }^{2}$ See al Amīr Muștafā al Shihābī, al Mustalahāt al Ilmìyah fí al Lughah al 'Arabiyah fi al Qadim wa al Hadith (Damascus, 1988), 41. 
After the war, those European colonialists (i.e., England and France) who occupied important parts of the Arab world were aware of the influence of Arabic in drawing the Arabs together and in binding their past to their present. Thus they fought Arabic by trying to replace it with their own languages as well as encouraging colloquial and regional dialects. The goals here were to stamp out classical Arabic, sever the links between Arabs, and stifle Arab national sentiment. In a speech delivered at the "Azbakiyah Club in Cairo in 1839 and entitled "Why Is the Power of Creativity Absent among Egyptians?," Sir William Wilcox claimed that the most important reason was the use of classical Arabic for reading and writing. He urged the adoption of the colloquial language as a means of literary expression, as other nations had done. He cited the example of England and added that it profited a great deal when it abandoned Latin, which was once the language of writing and education. ${ }^{3}$ In addition to encouraging local and regional dialects, the colonialists worked to introduce their own languages on a large scale. Both France and England made their respective languages the official languages in law courts and government administration and imposed them as the languages of education.

Among the early experiments in Arabization and using Arabic was that of Egypt's Muhammad 'Alī during the beginning of the nineteenth century. In his endeavors to build a strong army and to revive the Arab empire, he realized that he must rely on modem sciences and enhance scientific and technological applications in all fields. To realize these goals, he opened several military academies and schools of engineering, agriculture, medicine, and veterinary science. He also opened a madrasah al alsun (school of languages), started a newspaper called al Waqã' $i$ ' al Mișriyah (The Egyptian Gazette), and offered hundreds of scholarships to students to pursue their studies abroad.

Most remarkable was the fact that Arabic was the language of instruction in these educational establishments, including the Europeanstaffed medical school. Lectures given by European (mainly French) teachers were translated by professional and specialized translators, as were the following questions and answers. To acquaint these translators with the needed technical terms, they attended classes and were tutored by the instructors. Instructors were required to learn Arabic. Although this latter condition was difficult, several teachers excelled in it. For example, Dr. Perron compiled the first medical French-Arabic dictionary, which he entitled al Shudhür al Dhahabiyah fi al Mușțalahāt al Tibbiyah (The Golden Pieces in Medical Terms).

The death of Muhammad 'Alī did not seem to affect the progress of Arabization, for it continued under his successor Khedive Ismā'îl. Arabic 
was the official state language and the language of instruction at government schools until 1882, when the British entered Egypt and, under the pretext of reforming education, replaced it with English. This ended an Arabization experiment that had lasted for more than seventy years.

In Lebanon, another experiment in Arabization took place in 1866 at an institution known originally as the Syrian Protestant College, which was located in the village of Abieh. This college taught Arabic language and literature, mathematics, natural sciences, modern languages, law and jurisprudence, and medicine. The language of instruction was Arabic. In 1873 , the college moved to Beirut and was renamed the American University of Beirut (AUB).

Within the medical department, three foreign instructors (Cornelius Van Dyke, John Wortbet and George Post) mastered Arabic and made important contributions to Arabization. Not only did they fall back on the valuable textbooks produced in Egypt during the first half of the century, but they wrote their own-in Arabic. As a group, they produced twentythree college-level books on subjects ranging from physiology, chemistry, anatomy, and surgery to practical and clinical medicine. In his article "The Genesis and Early History of the Syrian Protestant College," A. L. Tibāwī gives a bibliographical list of these books and others printed by AUB. ${ }^{4}$ But in 1879 the Board of Managers decided to make English obligatory and, despite the protest and condemnation of the students and a number of instructors, Arabic ceased to be the language of instruction beginning with the academic year 1879-80. This decision ended another successful but short-lived Arabization experiment.

The end of this effort and the abandonment of Arabic led to an eclipse in the use of Arabic in the field of education until 1919. During that year, King Fayșal of Syria opened the Arabic College of Medicine in Damascus. From the first day, the language of instruction was Arabic. Such Arab teachers as Michael Shamindin al Dimashkī, a former member of staff at the Imperial School of Medicine in Constantinople, together with graduates from AUB's medical school (i.e., 'Abd al Rahmān Shāhbandar) soon joined. The teaching staff also featured several Arab medical specialists who wrote on their specialities and produced their own textbooks. Murshīd Khātir, for example, wrote a six-volume work on surgery. Ahmad Hamdī al Khayyāt wrote on microbiology and coined Arabic names for various kinds and shapes of germs and microbes, and Husnī Sabāh wrote a seven-volume work on internal diseases. By their hard work, these instructors and other staff members made the college a success and set a practical example of the resourcefulness and adaptability of Arabic.

${ }^{4}$ See A. L. Tibāwī, Arabic and Islamic Themes: Historical, Educational, and Literary Studies (London: 1976), 253-85. 
The effort to strengthen the use of Arabic and to acquaint the public with new scientific and medical terms was a continuous process. The Department of Health (Damascus) issued the first Arabic medical magazine (Public Health), which featured a series of articles on Arabic language and medicine. In 1923, the law college was opened. Soon, both colleges were known as The Syrian University. In 1924 the Journal of Arabic of the College of Medicine was issued and sought to "serve the Arabic language and to link the old Arabic medical sciences with modern sciences. ${ }^{\prime 5}$ It also published the views of linguists and specialists in Syria and other Arab countries on the meanings and connotations of the new terms introduced in the language. ${ }^{6}$

In 1920, Sātị ${ }^{`}$ al Hușrī, the Minister of Education, formed an official committee of specialists. These people were to examine every new term, study its origin, its equivalent in English and French, its translation in Egypt, Syria, and Turkey, its related meaning in old Arabic books, and then choose and adopt a suitable term. Along with these measures, the government established the Academy of Arabic Language in Damascus in 1919. This new institute started to collect old literary works and manuscripts, buy modern scientific books and references, print rare manuscripts, and give public lectures on literary and scientific subjects. It also started its own journal, Journal of the Academy of Arabic Language, which is still being used by members of the academy to publish their studies in literature and science. Its special focus is on language and scientific terms. In addition, the academy supplies government departments with equivalent Arabic terms for all foreign words that come their way.

After independence, the pace of Arabization accelerated. In 1955, a committee was formed and entrusted with translating the multilingual (French-English-German-Latin) Clairville Medical Dictionary. A year later, the committee produced a copy of a nine hundred sixty-page dictionary in Arabic. It contained fourteen thousand five hundred entries and was chosen as a reference for medical terms. In 1960, the Syndicate of Syrian Doctors started its Arabic Medical Quarterly, which was devoted to showing the suitability of Arabic for teaching medical sciences and conducting medical research. Thirty-three years have passed and it is still being published.

In 1958, several new colleges were established and formed the University of Damascus, which now has more than ten major colleges that teach arts and humanities, education, Islamic law, economy, medicine, civil engineering, architecture, dentistry, pharmacology, agriculture, fine

${ }^{5}$ See Husnī Șabāh, "Al Ma‘ājim al Tibbīyah wa Tawhīd al Muștalahāt al Tibbī" Majallat Majma' al Lughah al 'Arabiyah bi Dimashq, no. 59 (April 1984): 22.

${ }^{6}$ Publication of the Journal ceased in 1947. 
arts, and mechanical end electric engineering. The University of Aleppo, the second major Syrian university, was set up in Damascus during the same year. It has a comparable number of colleges in all fields of knowledge. In 1971, Latakiyah's Tishrīn University started and grew until its present size of nine major colleges. More recently, in 1979, the al Ba'ath University was opened in Homs. It now contains seven colleges.

In all of these universities, Arabic is the only language of instruction, and all textbooks and references are in Arabic. Each university has its own printing office that supplies it with its needs. In the printing office of the University of Aleppo alone, for example, 1,680 textbooks and academic references have so far been produced all in Arabic.

The method adopted by the university staff in introducing new terms followed certain steps. In order of priority, they are: a) searching in old Arabic books for a term with an equivalent meaning; b) searching for an old word or term with an analogous meaning that, with a little modification, can be adopted; c) searching for a new term within the accepted rules of derivation; and d) transliteration when translation and derivation are impossible.

Despite the success that Syria has achieved, there are still some obstacles affecting the progress of Arabization and the introduction of new terms. The most important ones are: a) the absence of a national center of translation and Arabization that could organize and coordinate all activities in the field of Arabization, especially the attempts of private individuals; b) the lack of incentive awards for the translation of modern technical and scientific subjects, particularly famous encyclopedias, periodicals, and important research papers; $c$ ) the rapid advance of modern science and technology, which results in a constant flow of new terms that need to be looked at and studied. The efforts expended by one single country, no matter how great, cannot cover all fields of knowledge. It requires the collective efforts and the combined actions of many Arab specialists and scholars; and d) although Syria has achieved considerable success in finding new terms, it still suffers from differences in translation among other Arab countries.

This last factor continues to hinder Arabization. To overcome it, a number of measures should be undertaken: a) continuous coordination and consultation among the academies of the Arabic language in the Arab world; b) organizing conferences, symposiums, and meetings for people who work in translation and Arabization in the Arab world; c) establishing a "supreme" institute at which scholars from all Arab countries would examine new terms, compare the different translations offered, and then choose the most appropriate one; and d) find some way to make the execution of the decisions taken in the field of translation and Arabization on the national level obligatory thoughout the Arab world. 